\title{
The Development Situation, Problems, and Countermeasures of the Cultural Goods in China
}

\author{
Yining Yang, a and Haiying $\mathrm{Ma}^{2, \mathrm{~b}^{*}}$ \\ ${ }^{1,2}$ School of Economics, Northwest University for Nationalities, Lanzhou (730124), P.R. China \\ a824272614@qq.com, blxmahaiying8888@163.com
}

Keywords: Cultural goods; Cultural trade; Cultural discount; Countermeasures

\begin{abstract}
With the further speeding of economic globalization and the improvement of people's living standard, people begin to pursue the spiritual enjoyment in their increasingly satisfying material life, and pay more and more attention to cultural goods. Therefore, the consumption of cultural activities and goods has continued to increase at a rapid clip, and are more discretionary. It means that the cultural goods are no longer a dispensable commodity or luxuries, which has become an indispensable part of economic reproduction process. In recent years, as the rapid development of Chinese trade of culture goods, a wide range of problems have accordingly arisen. Initially, this thesis gives a general introduction to cultural trade, and then collects the related data of cultural goods to analyze the current situation of Chinese cultural trade. After that, the thesis points out the existing problems and puts forward the suggestions.
\end{abstract}

\section{Introduction}

The 18th National Congress of the Communist Party of China puts forward the task that we must adhere to socialism orientation of advanced culture, build up self-confidence and proper pride of national culture, and march toward the goal of building a modern powerful socialist country (Qiao and Xin, 2012). Promoting socialist core value system construction is the important mission of cultural construction, which includes improving the moral qualities of the citizens, enriching spiritual life of the people, and increasing the overall strength and competitiveness of cultural. Meanwhile, the 13th Five-Year Plan for Economic and Social Development of China puts forward the goal that basically completing the system of public cultural services and pushing cultural industries to become a pillar of our national economy. All this shows that China has the resolve to strengthen the competitiveness of the cultural industry and promote the development of cultural trade.

Cultural trade has attracted much attention, and become the important components of international trade and global economy, which has significant meanings to the development of China. The development of cultural trade brings enormous economic efficiency, and promotes the development of the derivative industry; improves the status of structural unbalance, and stimulates exports to high-technology, high-value added goods; promotes cultural preservation, and implement the going global cultural strategy. Therefore, establishing a good reputation to increase international presence and enhance China's cultural soft power.

This paper gives a general introduction to cultural trade and the classification of cultural goods. Based on the UN Comrade Database for the period 2005-2013, I collected the international cultural goods data to analyze the current situation of China's international trade. Next, the paper found the causes which restrained the development of cultural goods. Finally, through the analysis and study sought the view of the problems existing and give some suggestions to promote the development of international trade of cultural goods.

\section{Overview of International Trade of Cultural Goods}

Cultural goods are defined as consumer goods that convey ideas, symbols and ways of life, i.e. books, magazines, multimedia products, software, recordings, films, videos, audio-visual programmer, crafts 
and fashion (UNESCO, 2009). Cultural goods are "experience goods meaning that consumers can determine their value only after they have been consumed" (OECD, 2008). Cultural goods are tangible and classified by their observable physical characteristics (UNESCO, 2016). The 2009 UNESCO FCS defines the culture sector which differentiates cultural domains from related domains as in Table 1).

Table 1 Cultural Domains

\begin{tabular}{|c|c|}
\hline A. Cultural and natural heritage & a. Antiques \\
\hline B. Performance and celebration & a. Musical instruments b. Recorded media \\
\hline C. Visual arts and crafts & $\begin{array}{l}\text { a. Paintings b. Other visual arts c. Craft d. } \\
\text { Jewellery f. Photography }\end{array}$ \\
\hline D. Books and press & a. Books b. Newspaper c. Other printed matter \\
\hline E. Audio-visual and interactive media & a. Film and video \\
\hline F. Design and creative services & a. Architecture and design \\
\hline
\end{tabular}

Source: UNESCO Institute for Statistics (UIS), 2009 UNESCO Framework for Cultural Statistics. 2009.

\section{The Development Situation of the Chinese Trade of Cultural Goods}

Recorded media data is missing in 2014 and 2015, so this paper used the trade data in 2006-2013 to analysis in order to protect the analysis results. Figure 1 provides the trends of export and import of Chinese cultural goods. From the total volume of trade, the trade of Chinese cultural goods increases at a high speed. The imports grew to US $\$ 5.8407$ billion in 2013 from US $\$ 2.6039$ billion in 2006, and the average annual growth rate of $12.23 \%$; the exports grew to US $\$ 60.1105$ billion in 2013 from US $\$ 15.7095$ billion in 2006, and the average annual growth rate of $21.13 \%$. From the balance of trade, China has maintained a trade surplus for many years, which rose to US $\$ 54.2699$ billion in 2013 and the average annual growth rate of $22.51 \%$. Meanwhile, the trade of Chinese cultural goods was affected by the economic and financial crisis of 2008. The cultural trade of goods declined in 2009 and started to recover in 2010.

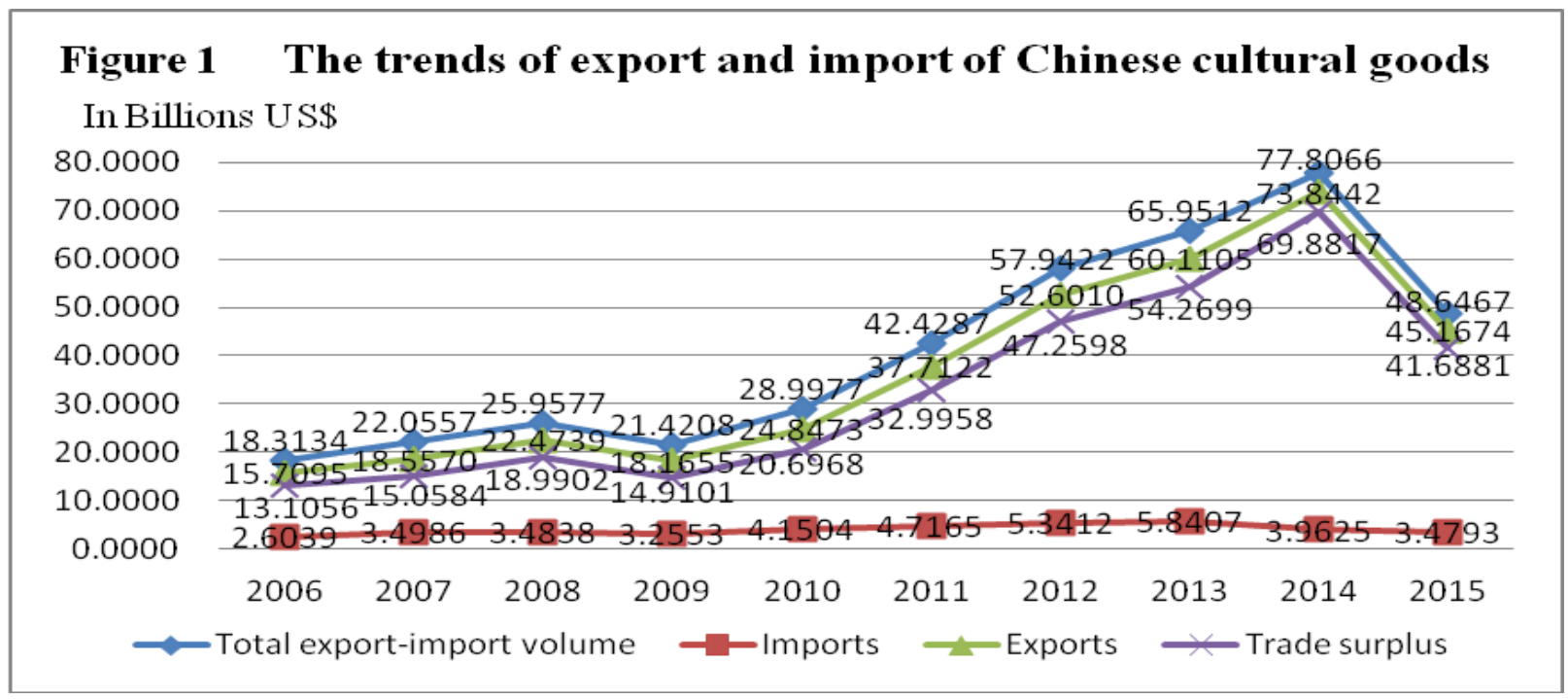

Source: UNESCO Institute for Statistics (UIS) based on data from UN Comtrade, DESA/UNSD, 2017 
Table 2 The balance of trade of Chinese cultural goods by 13 sections

Monetary unit: million US\$

\begin{tabular}{|c|c|c|c|c|c|c|c|c|c|}
\hline & 2007 & 2008 & 2009 & 2010 & 2011 & 2012 & 2013 & 2014 & 2015 \\
\hline Antiques & 0.9206 & -6.088 & 0.149 & -6.7 & -12.56 & -51.19 & -45.42 & -84.19 & -149.6 \\
\hline $\begin{array}{l}\text { Musical } \\
\text { instruments }\end{array}$ & 1019.9 & 1240.2 & 992.9 & 118 & 1294 & 1366 & 1308 & 1317 & 1262 \\
\hline $\begin{array}{l}\text { Recorded } \\
\text { media }\end{array}$ & -843.69 & -912.43 & -887.3 & -1468 & -1513 & -1885 & -1370 & - - & - \\
\hline Paintings & 85.851 & 111.10 & 58.08 & 127.9 & 260.9 & 315.6 & 344.0 & 332.6 & 497.2 \\
\hline $\begin{array}{l}\text { Other visual } \\
\text { arts }\end{array}$ & 3631.8 & 4076.5 & 3905 & 5309 & 7490 & 1223 & 1165 & 8948 & 8785 \\
\hline Craft & 2269.1 & 2424.4 & 1983 & 2464 & 2,923 & 3065 & 3603 & 4158 & 4242 \\
\hline Jewellery & 2595.8 & 2531.9 & 2522 & 6883 & 15691 & 23320 & 30840 & 48997 & 18159 \\
\hline Photography & -2.1596 & -7.6863 & -9.571 & -19.62 & -24.29 & -30.57 & -19.01 & -14.92 & -11.3 \\
\hline Books & 755.22 & 937.01 & 828.1 & 931.9 & 994.2 & 1051 & 935.4 & 990.6 & 937.3 \\
\hline Newspaper & -109.35 & -114.3 & -122.5 & -190.9 & -199.4 & -215.9 & -207.8 & -235.3 & -232.9 \\
\hline $\begin{array}{l}\text { Other printed } \\
\text { matter }\end{array}$ & 636.09 & 817.69 & 798.9 & 950.1 & 1158 & 1232 & 1350 & 1397 & 1387 \\
\hline $\begin{array}{l}\text { Film and } \\
\text { video }\end{array}$ & 4988.1 & 7884.5 & 4825 & 4530 & 4927 & 6851 & 5867 & 5382 & 8065 \\
\hline $\begin{array}{l}\text { Architecture } \\
\text { and design }\end{array}$ & 30.567 & 7.1798 & 13.45 & 2.691 & 6.271 & 4.885 & 4.157 & 7.697 & 6.828 \\
\hline
\end{tabular}

Source: UNESCO Institute for Statistics (UIS) based on data from UN Comtrade, DESA/UNSD, 2017

Data from Table 2 shows that the trade surplus mainly comes from jewellery, other visual arts, film and video, and Craft. The trade deficit mainly comes from recorded media, newspaper, antiques, photography. Visual arts and crafts made up most of exports of cultural goods from 2006 to 2015, and articles of jewellery accounted for the largest share of exports. The trade surplus of film and video is in the lead in the audio-visual and interactive media, but the surplus is primarily created by electronic game goods. Film and television are suffering from trade deficit, which have profound cultural connotations. Thus, there is an obvious gap between different domains of Chinese cultural goods, and trade structure was in a state of imbalance. The trade of cultural goods mare relies on the advantages for manufacture, which are mostly low value-added primary ones and lack of core competitiveness.

\section{Problems of the Development of Chinese Cultural Goods}

Lack of Cultural Goods Development Consciousness. Cultural industries are knowledge and technology-intensive industry, which puts forward higher requirements for the cultural creativity and the innovative talents. The shortage of talents has become the bottleneck of the development of cultural trade, which leads to the lack of innovation consciousness and using modern science and technology. At the same time, China is a country with an ancient civilization of five thousand years and a lot of cultural legacies, which have not been explored. It focused on the cultural exchange, but lacked the attention to the economic attribute of culture. If we do not seasonable development and effective utilization about traditional Chinese culture, it will be used to create economic value by other countries. For example, Kung Fu Panda is an American film which had a basis in traditional Chinese cultural elements.

Lack of Cultural Brand and Marketing Consciousness. What the development of cultural industry tells us is that we must build our own brands, expand the brand effect, integrate industrial chain, and promote the development of industrial cluster. Hollywood movie, Japanese cartoons, and 
Korean dramas have become one of the country's brands of trade about cultural goods. When consumer chooses to buy a piano, many consumers will buy Yamaha, Kawai, Steinway, etc. It is how the brand power in the market. The enterprises are no careful and deep research on international markets; propaganda dynamics is insufficient; and the channel of communication is not smooth. All these factors make many excellent goods lost the chance to shine in the international market, which are constrains the development of Chinese cultural trade.

Encounter the Cultural Discount. Cultural trade is rooted in the native culture, and cultural goods are the carrier of cultural information. It is appealing to people who are familiar with the cultural, but the attraction for the unfamiliar people will be heavily discounted. As a matter of the cultural differences, people from different area have different global view and values, and they will lose interest and ability to understand when contact with the unfamiliar cultural goods. This is called the cultural discount, which is unique feature of cultural goods (Zhi, 2013).

Imperfect Trade Policy and Management System. The management in the trade of Chinese cultural goods has multiple departments. For example, Guiding Directory on Cultural Products and Service Export revise by the Chinese Ministry of Commerce, the Publicity Department of the Communist Party of China, Foreign Ministry of China, Culture Ministry of China, the General Administration of Customs. It will cause the phenomenon of overlapping functions, multi-channel management, and low administrative efficiency. Moreover, the basic legal papers about the trade of cultural goods do not yet exist, which makes unsystematic about all rules and regulations. Therefore, some areas appear blank that there are no regulations, or the contents are repeated, which takes more difficult to implement policy.

\section{Countermeasures to Promote the Development of Trade of Chinese Cultural Goods}

The High-end Transformation of Cultural Goods. Talent is the intellectual foundation of high-end transformation of cultural goods. On the one hand, we need to change the traditional concept of employing people, and make the best use of human resources. On the other hand, it is necessary to speed up the cultivation of multi-skill innovation talents and improve the overall level of personnel in the field of trade of Chinese cultural goods. Cultural enterprises can cultivate these compound talents to adapt to the needs of development of cultural goods trade by training abroad or joint training with colleges. Therefore, it will provide a strong intelligence support to the Chinese cultural goods enter the world market. Therefore, enterprises should strengthen the integration with technology, improve their technological level and capabilities of resource development, and increase the added value of cultural goods, which will ultimately achieve the goal that enhance the overall strength of cultural trade and the international competitiveness.

Building Cultural Brand and Improving the Marketing. As an important intangible asset of enterprises, brand can bring huge economic benefits for the enterprise. Cultural trade wants to go out, which means we need to cultivate and develop several cultural enterprises with international competitiveness. Thus, the first thing is to create a national brand in the trade of cultural goods and then form them to be the world cultural brands with Chinese characteristics. We can ensure the status in the international cultural trade market and avoid disadvantages only when making Chinese cultural enterprises bigger. In the process of developing cultural enterprises, enterprises should broaden their thinking and fully realize the importance of brand strategy, and form the Chinese multinational companies through the cross-border investment, mergers, acquisitions, etc. For example, in 2012, Wanda Group cost \$2.6 billion to merge and acquire AMC Theatres (Jie and Lin, 2012). In 2016, Wanda Group once again announced that they would spend less than $\$ 3.5$ billion to merge and acquire Legendary Pictures (Culture, 2016).

Reduce the Cultural Discount. The negative effects of cultural discount restrict the long-term development of the trade of Chinese cultural goods, cut the international competitiveness. Hence, it is imperative to reducing the cultural discount. We should hold from the following respects. Firstly, we should consider the problems of the cultural differences during the creating period. Using the 
expressed in different ways that can be understand by the westerners is a good way to introduce the Eastern cultures, which is not depend on the simple language translation. Secondly, we should increase the psychological research about the foreign consumers, and choose the cultural goods which have the lower cultural discount to be the main force of cultural trade. Chinese Kung Fu, acrobatics, and dance have already gotten the high cognition degree in the international market. Third, we should build the evaluation system about cultural discount to evaluate the extent of encounter the cultural discount, and develop marketing strategy for different market by market segmentation.

Perfect the Policy, Management, and Legal System. China should set strict standards for the management institutions and functions, establish the corresponding long-term mechanism, and accelerate improvement in the legal system. Firstly, the government function must be transformed, and we should establish special sections to cultural trade. It will give full play to the government functions, make an overall arrangement, optimize resources distribution, and give more support to the cultural trade. Next, we should classify the related rules and regulations of trade of cultural goods, find out the defects, amending the outdated terms, and covers the void of domain. Then, we should stabilize, improve and strengthen policies supporting trade of cultural goods. Establishing scientific, reasonable, and valid industry support policy to the different industry will help the Industrial development. Finally, we should strengthen and improve the legislation of the intellectual property to protect the intellectual property. Literary and art workers or enterprises feel more motivation to create the better cultural goods when their innovative goods are under the protection.

\section{Conclusion}

We can see that Chinese cultural trade have made remarkable achievements, but the questions still exist. This paper holds that the problems existing in the cultural trade of our country are as follows: lack of awareness of developing the cultural products, lack of the cultural brand, encountering the cultural discount, the management of the cultural trade and the imperfect policy system. Based on these problems, some proposals are put forward. From my point of view, the maintenance of the international position of the cultural trade depends on these as follows: emphasizing the role of talents and technology, promoting the transformation of the cultural trade into the high-end one, constructing the cultural brand through various approaches, making clear the importance of marketing, formulating the specific marketing strategies for different products, reducing the cultural discount from many aspects, constructing the evaluation system of culture, choosing the target market and improving the systems of management, policy and the law so as to create a favorable external environment for the cultural trade.

\section{References}

[1] Yugang Yan, The Cultural Discount and the Product Strategy of Chinese Cultural Trade. Modern Economic Research. 2 (2008):52-53.

[2] Zhicai, Ding. The Ethnic Culture Industry and International Communication. Academic Forum 8 (2013)161-163.

[3] UNESCO Institute for Statistics (UIS). The Globalization of Cultural Trade: A Shift in Consumption. Montreal, UIS, 2016.

[4] Li Jiashan, Yang Pinqiu. Cultural trade: the rational choice of Chinese culture going out, 2010 annual report on China's foreign cultural trade, Beijing, Peking University Press, 2011

[5] Hu Huilin, China's national cultural security report, Taiyuan: Shanxi People's Publishing House, 2005.

[6] Hua Jian, Cultural dance on the industrial interface, Shanghai: Shanghai People's Publishing House, 2002.

[7] Yang Wu, Study on the culture and art of ASEAN, Harbin: Harbin Engineering University Press, 2007. 
[8] Cheng Manli, Wang Weijia. Study on the effect of foreign communication and communication, Beijing: Peking University Press, 2011.

[9] Gao Weihua. Media cultural responsibility and national cultural communication, news enthusiast, 10(2007). 